\title{
Peningkatan Kuat Tarik Bioplastik dengan Filler Microfibrillated Cellulose dari Batang Sorgum
}

\author{
Yuli Darni ${ }^{1, *}$, Lia Lismeri ${ }^{1}$, Muhammad Hanif ${ }^{1}$, Sarkowi ${ }^{2}$, Dita Synthauli Evaniya ${ }^{1}$ \\ ${ }^{1}$ Jurusan Teknik Kimia, Fakultas Teknik, Universitas Lampung \\ ${ }^{2}$ Jurusan Teknik Geofisika, Fakultas Teknik, Universitas Lampung, Jl. Prof. Dr. Soemantri Brodjonegoro No. 1 Bandar \\ Lampung 35145 \\ *e-mail: yuli.darni@eng.unila.ac.id
}

\begin{abstract}
Abstrak. Penelitian ini membahas tentang pengaruh rasio pati terhadap kitosan (dalam basis berat) dan konsentrasi microfibrillated cellulose sebagai filler dalam pembuatan bioplastik menggunakan pati sorgum, kitosan dan gliserol. Dalam penelitian ini, rasio pati terhadap kitosan yang divariasikan adalah 10:0, 9,5:0,5, 8,5:1,5, 7,5:2,5, 6,5:3,5, 5,5:4,5 (gr/gr). Microfibrillated cellulose sebagai filler disintesis dari batang sorgum dengan metode semimekanis. Perlakuan kimia diawali dengan delignifikasi batang sorgum dengan $\mathrm{KOH} \mathrm{4 \%} \mathrm{pada} \mathrm{temperatur} 80^{\circ} \mathrm{C}$ selama 1 jam untuk menghilangkan lignin. Setelah itu dicuci dan dipucatkan (bleaching) sebanyak dua kali menggunakan $\mathrm{H}_{2} \mathrm{O}_{2} 6 \%$ pada suhu $70^{\circ} \mathrm{C}$. Serbuk batang sorgum yang sudah kering dilanjutkan dengan perlakuan mekanis yaitu dimasukkan ke dalam disk mill selama 90 menit dan dilanjutkan dengan high energy milling (HEM) untuk mengecilkan ukurannya sampai dengan rata-rata 4-8 $\mu \mathrm{m}$. Filler ditambahkan, dan konsentrasinya (dalam basis berat) divariasikan dari 0, 1, 2, dan $3 \%$. Pati dan kitosan berukuran 63 mikron (lolos ayakan), waktu pengadukan selama 35 menit pada kecepatan $375 \mathrm{rpm}$, dan penambahan 10\% berat gliserol sebagai plasticizer dijaga konstan. Hasil terbaik pada penelitian ini diperoleh pada formulasi 8,5:1,5 (gr/gr). dan konsentrasi filler 3\%. Produk bioplastik ini memiliki kuat tarik 11,64 MPa, persen perpanjangan 10,98\%, modulus Young 105,96 MPa, densitas 0,915 gr/ml, dan penyerapan air 38,3\%.
\end{abstract}

Kata kunci: bioplastik, gliserol, kitosan, microfibrillated cellulose, sorgum.

Abstract. The Improving of Bioplastic Tensile Strength with Microfibrillated Cellulose Filler from Sorghum Stem. This study discusses the effect of starch on chitosan ratio (in weight basis) and also the concentration of microfibrillated cellulose as a filler in the preparation of bioplastics using sorghum starch, chitosan, and glycerol. In this study, the ratio of starch to chitosan varied was 10:0, 9.5:0.5, 8.5:1.5, 7.5:2.5, 6.5:3.5, 5.5:4,5 (gr/gr). Microfibrillated cellulose as filler was encouraged from the sorghum stem by the semi-mechanical method. The delignification of sorghum stem initiated chemical treatment with a $4 \% \mathrm{KOH}$ solution on $80^{\circ} \mathrm{C}$ for 1 hour to remove lignin. Bleaching is done after delignification using $6 \% \mathrm{H}_{2} \mathrm{O}_{2}$ at $70^{\circ} \mathrm{C}$. The dried sorghum powder is further followed by mechanical treatment that is put into disk mill for 90 minutes and continued with high energy milling (HEM) to reduce its size to an average of 4-8 $\mu \mathrm{m}$. The filler is added, and the concentration (on a weight basis) varies from 0, 1, 2, and 3\%. Starch and chitosan measuring 63 microns (sieve pass), stirring time for 35 minutes at a speed of 375 rpm, and the addition of $10 \%$ by weight of glycerol as a plasticizer is kept constant. The best results in this study were obtained in formulations 8.5:1.5 (gr/gr) and 3\% filler concentration. This bioplastic product has $11.64 \mathrm{MPa}$ tensile strength, $10.98 \%$ elongation, $105.96 \mathrm{MPa}$ Young moduli, $0.915 \mathrm{gr} / \mathrm{ml}$ density, and $38.3 \%$ water uptake.

Keywords: bioplastic, chitosan, glycerol, microfibrillated cellulose, sorghum.

\section{Graphical Abstract}

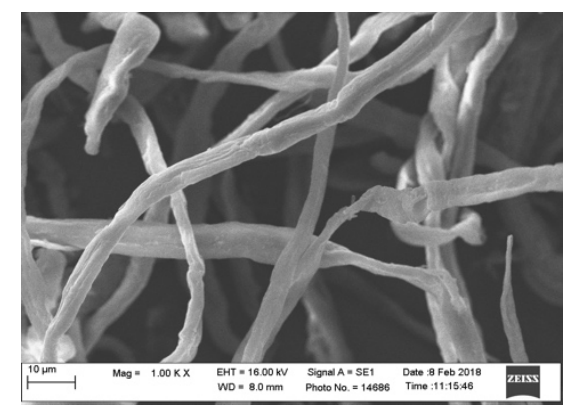

\section{Pendahuluan}

Dewasa ini, plastik konvensional merupakan salah satu bahan yang digunakan untuk mempermudah kehidupan manusia karena ringan dan ekonomis. Namun, penggunaan plastik terus menerus dapat meningkatkan permasalahan lingkungan, karena plastik jenis ini memiliki tingkat degradabilitas yang rendah. Hal tersebut menyebabkan plastik konvensional akan sulit 
terdegradasi oleh bakteri-bakteri pengurai, sehingga terjadinya penumpukan plastik yang menyebabkan permasalahan lingkungan. Meninjau besarnya dampak negatif pada lingkungan yang dapat terjadi, dibutuhkan sebuah inovasi dalam pembuatan plastik yang mudah terdegradasi secara biologis. Salah satu inovasi yang dapat dilakukan adalah pembuatan plastik biodegradable yang dapat menyamai karakteristik plastik konvensional (Elpita dan Darni, 2015).

Plastik biodegradable yang sering disebut dengan bioplastik merupakan plastik yang dapat digunakan layaknya plastik konvensional tetapi dapat terdegradasi secara alami. Bioplastik yang dihasilkan terbuat dari polimer alam, yaitu polisakarida dan protein (Hartatik dkk., 2014). Salah satu polisakarida yang digunakan dalam penelitian ini adalah pati tanaman sorgum. Tanaman sorgum (Sorghum bicolor L.) merupakan tanaman jenis serealia yang memiliki potensi untuk dikembangkan dan dibudidayakan, khususnya di daerah kering yang banyak di Indonesia dengan kandungan pati $80,42 \%$ (Badan Litbang Pertanian, 2013). Namun, bioplastik berbahan pati memiliki kekurangan yaitu rendahnya kuat tarik bioplastik yang dihasilkan dan tingginya tingkat penyerapan air. Oleh karena itu, bioplastik berbahan dasar pati perlu dicampurkan dengan kitosan (biopolimer) yang dapat menurunkan tingkat penyerapan air karena bersifat hidrofobik (Darni dan Utami, 2010), sedangkan untuk meningkatkan kuat tarik dari bioplastik, perlu ditambahkan filler (Wicaksono dkk., 2013).

Penambahan filler pada dasarnya dapat meningkatkan kuat tarik pada bioplastik. Filler yang ditambahkan akan menempati rongga antar penyusun bioplastik dan membuat kontak permukaan pada bioplastik semakin besar dan rapat. Hal ini dapat dipengaruhi oleh ukuran filler yang digunakan. Semakin kecil ukuran filler yang digunakan, maka permukaan bioplastik yang dihasilkan akan semakin rapat dan memiliki kontak permukaan semakin besar. Oleh karena itu, pada penelitian ini telah dikaji pengaruh formulasi antara pati sorgum:kitosan terhadap konsentrasi Microfibrillated Cellulose (MFC) sebagai filler. Micro Filler cellulose dalam ukuran mikrometer atau nanometer secara signifikan mempengaruhi sifat matriks polimer pada bioplastik. Micro filler cellulose dalam bioplastik dapat mempengaruhi sifat material karena memiliki rasio luas permukaan dan volume yang tinggi. Microfibrillated celullose merupakan selulosa yang mengalami perlakuan pemisahan serat menjadi mikrofibril-mikrofibril dengan kisaran diameter 10-100 nm dan panjang beberapa mikrometer (Winuprasith dan Suphantharika, 2013). Pada penelitian ini diameter filler yang digunakan lebih kecil dibandingkan penelitian sebelumnya yang masih berukuran 63 mikron (Darni dkk., 2015). Pada penelitian sebelumnya tersebut hanya dilakukan pengecilan ukuran saja atau secara mekanik terhadap batang sorgum sebagai filler, sedangkan pada penelitian ini dilakukan proses alkali-mekanik terhadap batang sorgum, yang mengacu pada penelitian Wicaksono, dkk. (2013) dengan bahan baku ampas tapioka.

\section{Metodologi}

\subsection{Bahan dan alat}

Bahan yang digunakan adalah batang sorgum dan biji sorgum yang didapatkan dari BPTP Lampung, Kalium Hidroksida $(\mathrm{KOH})$, Peroksida $\left(\mathrm{H}_{2} \mathrm{O}_{2}\right)$, Kitosan, Gliserol, Asam Asetat $\left(\mathrm{CH}_{3} \mathrm{COOH}\right)$ dan aquades. Instrumen pengujian yang digunakan adalah Imstron Series IX version 8.27.00, Scanning Electron Microscope ZEIZZ EVO MA 10. Alat untuk pembuatan MFC dan sintesis bioplastik berupa beaker glass, hot plate, stirrer, thermometer, oven dan cetakan bioplastik.

\subsection{Sintesis MFC}

Metode pembuatan MFC sebagai filler pada penelitian ini adalah metode semi mekanis yang telah dilakukan oleh Wicaksono dkk. (2013). Proses diawali dengan delignifikasi yaitu serbuk batang sorgum yang telah dikecilkan sampai dengan ukuran 100 mesh ditimbang sebanyak 10 gr, kemudian ditempatkan dalam gelas ukur volume $500 \mathrm{ml}$. Batang sorgum tersebut kemudian direndam dan diaduk dengan larutan $\mathrm{KOH} 4 \%$ pada temperatur $80^{\circ} \mathrm{C}$ selama 1 jam. Setelah itu batang sorgum dicuci dan dipucatkan (bleaching) sebanyak dua kali menggunakan $\mathrm{H}_{2} \mathrm{O}_{2} 6 \%$ pada suhu $70^{\circ} \mathrm{C}$ masingmasing selama 1 jam sambil diaduk. Bahan yang telah dicuci, kemudian direndam dan diaduk dengan larutan $\mathrm{KOH} 4 \%$ pada suhu $80^{\circ} \mathrm{C}$ selama 1 jam. Untuk tahap akhir, bahan tersebut dicuci hingga menghasilkan $\mathrm{pH}$ air cucian menjadi 7 dari $\mathrm{pH}$ awal yaitu 12. Setelah dicuci, serbuk batang sorgum dkeringkan dengani oven pada suhu $100^{\circ} \mathrm{C}$ selama 3 jam. Serbuk batang sorgum yang sudah kering dilanjutkan dengan perlakuan mekanis yaitu dimasukkan ke dalam disc mill selama 90 menit dan dilanjutkan dengan high energy milling (HEM) untuk mengecilkan ukurannya sampai dengan rata-rata 4$8 \mu \mathrm{m}$. MFC yang dihasilkan diuji karakteristiknya dengan scanning electrone micrograph (SEM).

\subsection{Sintesis bioplastik}

Prosedur pembuatan bioplastik merupakan modifikasi dari metode yang telah dilakukan oleh Ban (2006) mengikuti tahap-tahap berikut: pati sorgum dan kitosan ditimbang dengan perbandingan 9,5;0,5 gr/gr. Kemudian kitosan dilarutkan dengan asam asetat $90 \%$ dengan konsentrasi kitosan 20\%, sehingga didapatkan volume kitosan sebesar $2,5 \mathrm{ml}$. Setelah itu, pati dicampurkan dengan aquades 196,7 $\mathrm{ml}$ dan selanjutnya dicampurkan dengan larutan kitosan pada gelas ukur 500 ml. Larutan pati;kitosan diletakkan di atas hot plate stirrer yang sudah diatur temperaturnya pada $95^{\circ} \mathrm{C}$ sambil diaduk pada kecepatan $375 \mathrm{rpm}$. Gliserol 10\% berat atau sebanyak $0,8 \mathrm{ml}$ dicampurkan ke dalam larutan pati dan kitosan. Campuran ini diaduk hingga homogen, kemudian ditambahkan 1\%(berat) MFC sebanyak 0,1 gr. Campuran bioplastik kemudian diaduk terus selama 35 menit. Setelah itu, campuran diangkat dan dibiarkan sampai suhu kamar, lalu dituangkan sebanyak $100 \mathrm{ml}$ ke dalam cetakan dan dikeringkan dalam oven pada temperatur $60^{\circ} \mathrm{C}$ selama10 jam. Setelah itu dimasukkan kedalam zipbag lock dan disimpan dalam 
desikator. Langkah-langkah tersebut diulang dengan variasi formulasi pati;kitosan 10;0, 8,5;1,5, 7,5;2,5, 6,5;3,5, dan 5,5;4,5 (gr;gr) dan konsentrasi MFC 0\%, 2\% dan $3 \%$ wt. Produk bioplastik selanjutnya diuji karakteristik mekaniknya.

\subsection{Pengujian sifat mekanik}

Karakteristik sifat mekanik suatu bahan dipengaruhi oleh banyak faktor, salah satunya adalah rasio pati-selulosa. Karakteristik ini ditunjukkan oleh perbedaan nilai kuat tarik, persen perpanjangan, dan modulus young pada setiap bioplastik.

\subsubsection{Kekuatan tarik}

Proses pengujian kekuatan tarik dilakukan dengan menggunakan alat Universal Testing Machine (UTM) dengan merk INSTRON yang terdapat di Laboratorium Terpadu, Departemen Hasil Hutan, Institut Pertanian Bogor. Pengujian dilakukan berdasarkan standar ASTM D 882-97. Proses pengujian kekuatan tarik dilakukan berdasarkan standar ASTM D 882-97. ASTM D 882-92 merupakan standar pengukuran kekuatan tarik film plastik yang sangat tipis (thin plastic sheeting) dengan ketebalan kurang dari $1 \mathrm{~mm}$. Pengujian dilakukan dengan standar ini karena bioplastik yang dihasilkan mempunyai ketebalan 0,05 mm (kurang dari $1 \mathrm{~mm}$ ).

Sampel yang akan diuji dikondisikan terlebih dahulu dalam ruang climatic chamber dengan suhu dan kelembaban relative standar $\left(23^{\circ} \mathrm{C}, 50 \%\right)$ selama 48 jam. Pengujian dilakukan dengan cara ujung sampel dijepit mesin penguji tensile. Selanjutnya dilakukan pencatatan ketebalan dan panjang awal sampel. Tombol start ditekan kemudian alat akan menarik sampel dengan kecepatan $500 \mathrm{~mm} /$ menit sampai sampel putus. Nilai kekuatan tarik didapatkan dari hasil pembagian tegangan maksimum dengan luas penampang melintang. Tegangan maksimum didapatkan dari nilai tegangan sampel saat putus. Luas penampang melintang didapatkan dari hasil perkalian panjang awal sampel dengan ketebalan awal sampel. Uji kekuatan tarik dilakukan pada lima sampel bioplastik yang kemudian dihitung rata-ratanya. Kekuatan tarik bioplastik dihitung dengan persamaan berikut:

$$
\tau=\frac{F_{\max }}{A}
$$

\subsubsection{Kekuatan tarik}

Perpanjangan merupakan salah satu cara dalam pengukuran keliatan (keuletan) suatu bahan yang diperoleh dari uji tarik. Pengukuran ini didapat setelah terjadi putus atau regangan teknik pada saat putus $(\varepsilon)$. Nilai perpanjangan biasanya dinyatakan dalam persentase.

$$
\varepsilon=\frac{\mathrm{L}_{1}-\mathrm{L}_{0}}{\mathrm{~L}_{\mathrm{o}}} \times 100 \%
$$

\subsubsection{Modulus young (elastisitas)}

Gradien bagian linier awal kurva tegangan regangan adalah modulus elastisitas. Modulus elastisitas adalah ukuran kekakuan suatu bahan. Makin besar modulus elastisitas, makin kecil regangan elastis yang dihasilkan akibat pemberian tegangan.

$\mathrm{E}=\frac{\sigma}{\varepsilon}$

\section{Hasil dan Pembahasan}

\subsection{Karakteristik MFC}

Pada penelitian ini, batang sorgum mengalami perlakukan kimia dan mekanik sehingga dapat dihasilkan cellulose filler yang memiliki ukuran partikel antara 4-8 $\mu \mathrm{m}$. Jika dilihat dari ukuran partikelnya, cellulose filler ini dikategorikan dalam Microfibrillated Cellulose (MFC) (Wicaksono dkk., 2013). Uji yang dilakukan pada MFC adalah uji komposisi dan Scanning Electron Micrograph (SEM) untuk mengetahui morfologinya. Tabel 1 menunjukkan komposisi lignoselulosa pada batang sorgum sebelum dan sesudah delignifikasi. Berdasarkan Tabel 1 dapat dilihat bahwa setelah perlakuan kimia komposisi hemiselulosa dan lignin pada batang sorgum menurun sangat signifikan.

\subsection{Morfologi MFC}

Morfologi MFC sebagai filler dapat dilihat pada Gambar 1. Diameter MFC yang dihasilkan pada penelitian ini antara 4-8 $\mu \mathrm{m}$. Diameter yang dihasilkan lebih kecil jika dibandingkan dengan cellulose filler yang dihasilkan oleh Darni dkk. (2015) yaitu $63 \mu \mathrm{m}$. Perbedaan perlakuan yang digunakan dapat mempengaruhi ukuran serat yang terbentuk. Pada penelitian sebelumnya hanya menerapkan metode mekanik saja, sedangkan pada penelitian ini diberikan perlakuan alkali-mekanik terhadap batang sorgum.

Penurunan kadar lignin dan hemiselulosa juga mempengaruhi MFC yang terbentuk. Jika dilihat pada Tabel 1, terjadi penurunan yang sangat signifikan pada kandungan hemiselulosa dan lignin. Hal ini disebabkan oleh perlakuan alkali yang diberikan pada batang sorgum. Perlakuan alkali menyebabkan hemiselulosa terhidrolisis dan larut dalam air, sedangkan proses bleaching dapat menghilangkan sebagian besar lignin (Wicaksono dkk., 2013). Perlakuan mekanik dengan menggunakan pengadukan berkecepatan tinggi, dapat membelah serat, sehingga menghasilkan diameter yang lebih kecil.

Tabel 1. Kandungan serbuk batang sorgum sebelum dan sesudah perlakuan

\begin{tabular}{lccc}
\hline \multicolumn{1}{c}{ Kondisi } & $\begin{array}{c}\text { Hemiselulosa } \\
(\%)\end{array}$ & $\begin{array}{c}\text { Selulosa } \\
(\%)\end{array}$ & $\begin{array}{c}\text { Lignin } \\
(\%)\end{array}$ \\
\hline $\begin{array}{l}\text { Sebelum } \\
\text { delignifikasi }\end{array}$ & 23,4755 & 42,0338 & 12,6190 \\
$\begin{array}{l}\text { Sesudah } \\
\text { delignifikasi }\end{array}$ & 4,4374 & 86,7570 & 1,7556 \\
\hline
\end{tabular}




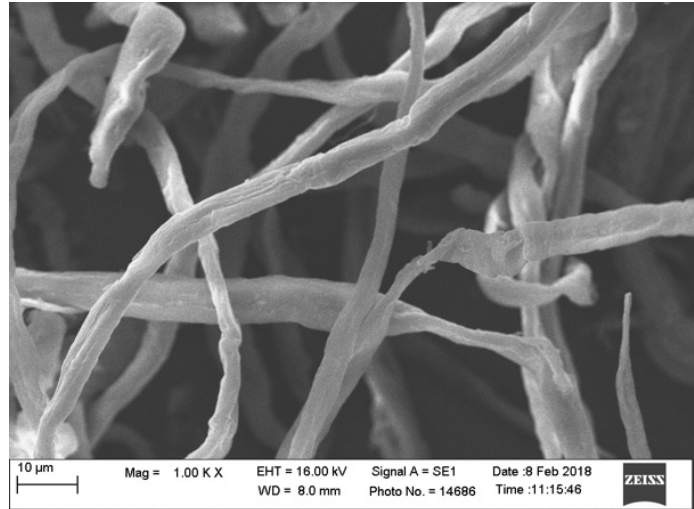

Gambar 1. Hasil analisis SEM MFC dengan perbesaran $1000 \mathrm{x}$

\subsection{Kuat tarik bioplastik}

MFC yang dihasilkan akan digunakan bersama dengan kitosan dalam pembuatan bioplastik. MFC digunakan sebagai filler untuk meningkatkan kuat tarik bioplastik berbasis sorgum, sedangkan kitosan yang bersifat hidrofobik berfungsi sebagai campuran biopolimer yang dapat menurunkan penyerapan air pada bioplastik yang dihasilkan. Hasil pengujian kuat tarik dan perpanjangan pada bioplastik berbasis sorgum dapat dilihat pada Gambar 2.

Gambar 2A menunjukkan bahwa penambahan MFC meningkatkan kuat tarik bioplastik sampai dua kali lipat dari sebelum penambahan MFC. Kuat tarik tertinggi dimiliki oleh bioplastik pada formulasi pati;kitosan 8,5;1;5 dengan MFC filler 3\%wt yaitu 11,64 Mpa. Kuat tarik bioplastik akan meningkat seiring dengan penambahan kitosan dan MFC filler. Hal ini disebabkan oleh ukuran diameter yang dimiliki oleh MFC filler dapat memperluas kontak permukaan antara serat dengan bioplastik (Wicaksono dkk., 2013). Namun, pada kondisi tertentu kuat tarik akan menurun. Penurunan kuat tarik ini disebabkan oleh kondisi jenuh pada matrik bioplastik, sehingga serat yang ditambahkan terus menerus tidak dapat terdistribusi. Faktor lain terjadinya penurunan kuat tarik adalah pencampuran yang tidak merata antara campuran penyusun bioplastik.

Peningkatan kuat tarik seiring dengan penambahan MFC filler dan kitosan ternyata berbanding terbalik dengan perpanjangan bioplastik. Perpanjangan terbesar dimiliki oleh bioplastik pada formulasi pati:kitosan 10:0 gr/gr dengan MFC filler $0 \%$ yaitu 21,42\%. Penurunan perpanjangan pada bioplastik disebabkan oleh interaksi MFC filler dengan pati yang menghalangi interaksi antara pati dan air (Wicaksono dkk., 2013).

Tabel 2. Perbandingan sifat fisik dan sifat mekanik dari plastik komersial dengan produk bioplastik

\begin{tabular}{llll}
\hline No & Sifat Plastik & *LDPE & Bioplastik \\
\hline 1 & Kuat Tarik( Mpa) & $8-31.4$ & 11.64 \\
2 & Persen Perpanjangan (\%) & $150-600$ & 10.98 \\
3 & Modulus young(MPa) & $100-250$ & 105.96 \\
\hline
\end{tabular}

*Akay, 2012

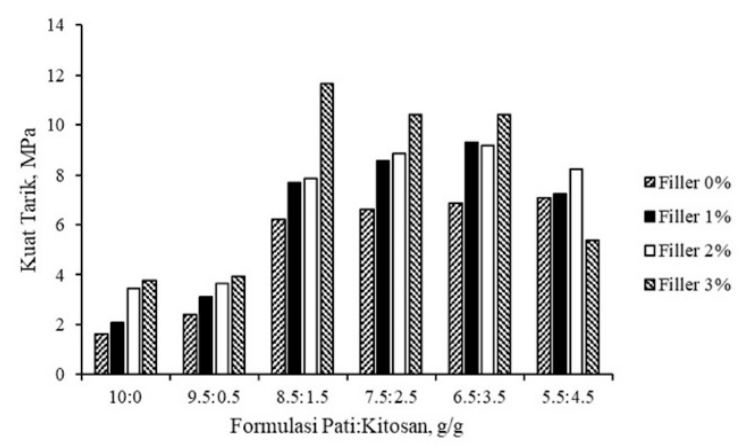

(a)

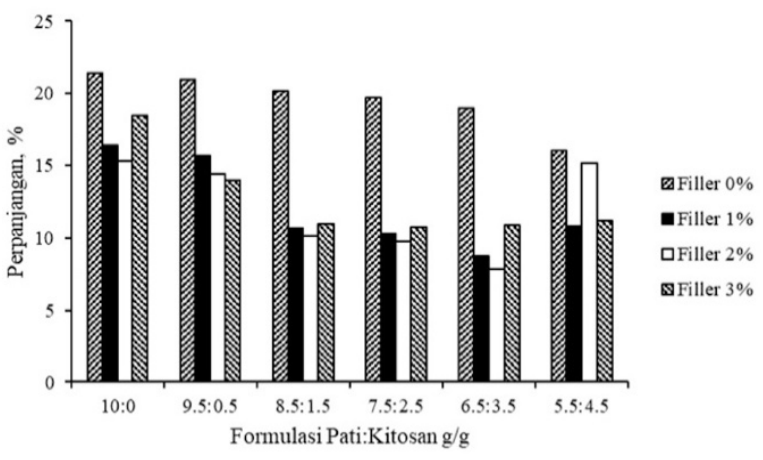

(b)

Gambar 2. Pengaruh formulasi pati:kitosan dan konsentrasi filler terhadap kuat tarik bioplastik (a), dan persen perpanjangan bioplastik (b)

Kuat tarik bioplastik yang dihasilkan mengalami kenaikan seiring dengan penambahan kitosan. Pada umumnya kitosan memang mempunyai fungsi sebagai bahan penguat yang dicampurkan ke dalam bioplastik. Namun, seiring dengan bertambahnya kitosan, ternyata kuat tarik mengalami penurunan (Gambar A), terlihat bahwa kuat tarik tertinggi pada formulasi kitosan 8,5:1,5 gr/gr. Hal itu membuktikan bahwa, adanya kondisi optimum pada formulasi bioplastik ini, penambahan kitosan terus menerus tidak serta merta menambah kuat tariknya. Hasil yang didapat telah sesuai dengan penelitian terdahulu, yaitu dengan kandungan kitosan yang semakin besar maka, semakin besar juga kuat tarik pada bioplastik (Darni dkk., 2015).

\section{Kesimpulan}

Serat selulosa yang dihasilkan pada penelitian ini memiliki diameter 4-8 $\mu \mathrm{m}$. Ditinjau dari diameter yang dimiliki, serat selulosa yang dihasilkan dari penelitian ini tergolong pada microfibril cellulose (MFC). Perlakuan alkali-mekanik dapat menurunkan kadar hemiselulosa dan lignin sampai $80 \%$. Karakteristik bioplastik dengan formulasi pati:kitosan 8,5:1,5 gr/gr dan konsentrasi filler 3\% memiliki kecenderungan menyerupai plastik konvensional LDPE dengan kuat tarik 11,64 Mpa, Modulus Young 105,96 Mpa. Penambahan MFC filler meningkatkan kuat tarik bioplastik sampai dua kali lipat dibandingkan dengan tanpa filler. 


\section{Ucapan Terima Kasih}

Peneliti mengucapkan terima kasih kepada Kemenristek DIKTI yang telah mendanai penelitian ini melalui Hibah Penelitian Produk Terapan (PPT) 2017 tahun anggaran 2017 dengan nomor kontrak 071/SP2H/LT/DPRM/2017.

\section{Daftar Notasi}

$\tau \quad:$ kekuatan tarik (MPa)

Fmax : tegangan maksimum $(\mathrm{N})$

A : luas penampang melintang $\left(\mathrm{mm}^{2}\right)$

Lo : panjang awal spesimen $(\mathrm{mm})$

$\mathrm{L}_{1} \quad$ : panjang spesimen saat diberi gaya tarik maksimum $(\mathrm{mm})$

$\sigma \quad:$ kuat tarik (MPa)

$\varepsilon \quad$ : perpanjangan (\%)

\section{Daftar Pustaka}

Akay, M., Introduction to Polymer Science and Technology. United Kingdom: Bookboon, 2012.

Badan Litbang Pertanian, Potensi dan Teknologi Penanganan Sorgum Sebagai Olahan Pangan. Agroinovasi Sinar Tani, 2011, 11-16.

Ban, W.; Song, J.; Dimitris, S.A.; Lucianus, A.L., Improving The Pysical and Chemical Functionally of Starch-derived Films with Biopolymers. Journal of Applied Polymer Science, 2006, 100, 2545-2548.

Darni, Y.; Utami, H., Studi Pembuatan dan Karakteristik Sifat Mekanik dan Hidrofobisitas Bioplastik dari Pati
Sorgum. Jurnal Rekayasa Kimia dan Lingkungan, 2010, 7(4), 88-93.

Darni, Y.; Darmansyah; Lismeri, L.; Binur, The Utilization of Sorghum Rod Powder as Filler to Enchance Mechanical Strength in Bioplastics Synthesis. International Conference on Science Technology and Interdiciplinary Research 2015, Bandar Lampung, 21-23 September, 2015.

Elpita, F.Y.; Darni, Y., Peningkatan Karakteristik Mekanik dan Fisik Bioplastik Berbahan Dasar Pati Sorgum dan Serbuk Batang Sorgum. Semnas Sains \& Teknologi VI, Bandar Lampung, 3 November, 2015.

Hartatik, Y.D.; Nuriyah, L.; Iswarin, Pengaruh Komposisi Kitosan Terhadap Sifat Mekanik dan Biodegredable Bioplastik. Brawijaya Physics Student Journal, 2014.

Wicaksono, R.; Syamsu, K.; Yuliasih, I.; Nasir, M., Karakteristik Nanoserat Selulosa dari Ampas Tapioka dan Aplikasinya sebagai Penguat Film Tapioka. Jurnal Teknologi Industri Pertanian, 2013, 23(1), 38-45.

Winuprasith, T.; Suphantharika, M., Microfibrillated Cellulose from Mangosteen (Garcinia mangostana L.) Rind: Preparation, Characterization, and Evaluation As An Emulsion Stabilizer. Food Hydrocolloid, 2013, 32(2), 383-394. 